\title{
Dreamscape into Landscape in Gavin Douglas
}

\section{CONOR LEAHY}

More than any other poet of the late Middle Ages Gavin Douglas knew how to describe the wind. It could have a 'lowde quhissilling' or a 'softe piping'; could blow in 'bubbys thik' or 'brethfull blastis'. Its rumbling 'ventositeis' could be 'busteous' or 'swyft' or 'swouchand'. On the open water, it could 'dyng' or 'swak' or 'quhirl' around a ship; could come 'thuddand doun' or 'brayand' or 'wysnand'. At times it could have a 'confortabill inspiratioun', and nourish the fields, but more typically it could serve as a harsh leveller, 'Dasyng the blude in euery creatur'. ${ }^{1}$ Such winds are whipped up across the landscapes and dreamscapes of Douglas's surviving poetry, and attest to the extraordinary copiousness of his naturalism. The alliterative tradition was alive and well in sixteenth century Scotland, but as Douglas himself explained, he could also call upon 'Sum bastard Latyn, French or Inglys' usages to further enrich 'the langage of Scottis natioun'. ${ }^{2}$

Douglas's translation of Virgil's Aeneid (1513) has itself occasioned a few blasts of hot air. John Ruskin described it as 'one of the most glorious books ever written by any nation in any language' and would often mention Douglas in the same breath as Dante. ${ }^{3}$ Ezra Pound breezily declared that the Eneados was 'better than the original, as Douglas had heard the sea' ${ }^{4}$ while T.S. Eliot, who later admitted to hardly knowing the work, nevertheless praised Douglas with consummate backhandedness as "perhaps the last great Scotch poet to write Scots with the same feeling toward the language, the same conviction, as an Englishman writing English' 5

For ordinary readers of poetry, however, Douglas's most attractive writing is to be found in his Prologues. These formally diverse and highly idiosyncratic works, 'annext' to each book of his translation, constitute the most inventive and comprehensive defence of poetry that had ever been attempted in Scots or English. As a literary critic, Douglas could be exacting, 
deferential, bullish, and irreverent; he tells us which books to throw to one side (Caxton's Eneydos), which to seek out (Boccaccio's Genealogia gentilium deorum), and which to read with a learned scepticism (Chaucer's Legend of Good Women). Most of all, he wishes to communicate the plurality of social and religious contexts in which poetry is written and read, and in his so-called 'prologues of natural description', he famously evokes the landscapes in which he himself came to write. Modernised in the age of James Thomson, and anthologised ever since, Douglas's extended evocations of winter (Prologue VII), summer (Prologue XII), and summer's waning (Prologue XIII), were admired by such practitioners of landscape as Thomas Sackville, Thomas Gray, and W.H. Auden, and have elicited generous praise from modern critics. ${ }^{6}$ In Derek Pearsall and Elizabeth Salter's Landscapes and Seasons of the Medieval World (1973), for instance, Douglas arrives triumphantly in the closing pages of the account, a miracle-man, ready to liberate the poetry of landscape from all narrative contingencies:

All the traditions of late medieval poetic landscape flow together and coalesce, miraculously, in Gavin Douglas. The Prologues to certain books of his translation of the Aeneid declare the independence of landscape description as a literary form for the first time, and manage to combine accuracy of detail and overall visual coherence in a way that makes Douglas the only poet comparable with the great Flemish landscape painters of the fifteenth and sixteenth century. (p. 200)

More recently, Alastair Fowler concluded an excellent essay on Douglas by describing him as 'effectively...the inventor of nature poetry'.

Since Douglas is still under-read and undervalued as a poet, this sort of informed advocacy is to be welcomed. Nevertheless, some qualifications should be made. Critical perspectives on the nature poetry of Douglas's antecedents have changed significantly in recent decades, affecting in turn the status of Douglas's own achievements. The old tendency to view the landscape writing of the fifteenth century vernacular as a drearily homogeneous tradition, characterised by 'tinsel-like glitter' and 'the canker of servile imitation', has thankfully abated. ${ }^{8}$ 
Readers no longer feel the need to generalise about a period that produced the hill-walking scene in Mum and the Sothsegger, the widening meadows of The Floure and the Leafe, or the studied textures of On Husbondrie. Landscape description can have a shifting range of associations at any given moment in time, or in the context of any given poem, and it is not necessary to caricature fifteenth century naturalism in order to champion Gavin Douglas.

Douglas himself could draw upon a diverse tradition of Scottish and English landscape poetry, both for specific details and for structural coherence. ${ }^{9}$ Although he had access to the writings of James I, Richard Holland, and William Dunbar, the most outstanding Scottish precedent was perhaps Robert Henryson's 'Preaching of the Swallow', in which a seasonal pattern suffuses and particularises the telling of a fable narrative. During a bitter winter, Henryson describes how the 'blastis boreall' will force the animals to withdraw into their dens:

All wyld beistis than from the bentis bair

Drawis for dreid vnto thair dennis deip,

Coucheand for cauld in coifis thame to keip.

$\left(\right.$ Fables, 11. 1703-05) ${ }^{10}$

Douglas expands this image evocatively in his seventh prologue: as 'Boreas' (the North wind) blows his 'bugill', the poet imagines not only how the deer will retreat into the valleys, and the birds into their hidden brambles, but also how the whales and dolphins - the 'Fludis monstreis' - will have to dive 'law in the deip' to avoid the turbulent waters of the surface (VII. Prol. 6772; 23-24). Douglas himself, 'Chiverrand for cauld', is forced to withdraw to the warmth of his fireplace, much like the elderly lover in Henryson's Testament of Cresseid (11. 27-28). Douglas could also rework Chaucer in surprising and original ways. Instead of turning to the opening of The Canterbury Tales for naturalism, for instance, he recalls the brief description in The House of Fame of 'thise lytel herde-gromes / That kepen bestis in the bromes' (11. 122526), ${ }^{11}$ and expands it for his seventh prologue: 
The silly scheip and thar litil hyrd gromys

Lurkis vndre le of bankis, woddis and bromys;

And other dantit grettar bestiall,

Within thar stabillis sesyt into stall

(VII. Prol. 77-80).

Douglas, it seems, was finely alert to moments of naturalism even when reading one of the wildest and most eccentric poems of the Middle Ages. His tactful elaboration has a freshness that is conspicuously lacking in some of the English emulations of Chaucer, the exordium of John Lydgate's Siege of Thebes being a notorious example.

Besides his intelligent use of vernacular sources, Douglas could permit a wealth of classical material to enter into his nature writing. He is apparently the first vernacular poet in Scotland or England to use Virgil's Georgics as a direct source, and he often turns to Ovid when describing the sunrise. (It is difficult to say whether Douglas's own description of dawn's 'russat mantill' was itself recalled by Horatio on the battlements of Elsinore.) ${ }^{12}$ It would seem that Douglas was never so deeply involved in the experience of nature as he was when reading or remembering poetry. The sensitivity of his response to his books allowed him to look searchingly and with fresh insight at the very landscape which 'daylie be experience we may se' ${ }^{13}$ But there is no fixed way of reading the nature prologues. Because of their positioning within the Eneados, many of their images seem to resonate with episodes in Virgil's epic, and even the most naturalistic of details may strike some readers in non-naturalistic ways. It is an open question, for instance, as to whether the geese in Prologue VII, 'Fleand on randon, schapyn like ane Y' (1. 120) are suggestive of Servius's moral interpretation of Aeneid VI, in which he likens the golden bough to 'the fork of the letter Y' (bivium Y litterae). ${ }^{14}$

In the foreground of these panoramic scenes, however, is a feature that has often been overlooked: Douglas's own earlier work. Very little attention has been given to the stylistic relationship between his exuberant dream vision The Palice of Honour (c.1501) and his Eneados, even though he himself took care to bind the two works together. Towards the end 
of the Palice, the figure of Venus presents a book to Douglas, commanding that it be 'put in ryme' (11. 1752), and at the end of the Eneados, he mentions that he has now fulfilled the pledge that he had made to Venus 'twelf 3heris tofor' ('Directioun', 11. 121). Douglas had changed considerably as a writer in those twelve years. As he moved from The Palice of Honour to the Eneados, his ideas about poetry became ever more subtle and exacting, and his use of comedy became more sophisticated, particularly in his prologue to Maffeo Vegio's 'thirteenth book' of the Aeneid. Most significantly, however, the intensely observed landscapes and dreamscapes of the Palice matured into the widely celebrated naturalism of the Eneados. If Douglas is indeed to be credited with 'the invention of landscape poetry in English', ${ }^{16}$ as Alastair Fowler proposes, then its invention must be seen as the product of a gradual poetic development, which took place over the course of a full career.

Although the literary sources and analogues of The Palice of Honour have been well documented, editorial comment has at times tended to dissolve rather than draw out what is most distinctive about the poem. Priscilla Bawcutt writes that the Palice is 'remarkable both for its wealth of literary allusion and for the way in which almost every theme or episode has some precedent in earlier medieval poetry', ${ }^{17}$ but such a point of departure is slightly misleading. In the hundred years following the death of Chaucer, no other dream vision written in Scotland or England was more inventive, more energetic, or more carefully structured than The Palice of Honour. It is a poem of dizzying heights and swirling comedy, but also one of melancholy and violence. Douglas's dreaming self is swept up into the 'Court Rethoricall', whose grand confraternity of muses, poets, and rhetoricians ranges breathlessly across the heavens. As they near the 'Palice of Honour' itself, they are witness to the eternal renown that awaits great writers, but as a mere apprentice, Douglas falls clumsily by the wayside. The high idealism of his vision bears an uncertain relationship to the swampier realities of life; his 
vaulting ambition is everywhere in evidence, not least when his dreaming self is being beaten up or falling into a ditch.

The sharpest, starkest contrast of the poem occurs between the idealised May garden of the dream prologue and the 'wildernes abhominabill' of the dream. The speaker is a young kirkman whose identity overlaps with that of the young cleric Gavin Douglas, ${ }^{18}$ and as he rises in the morning, and roams through lush vegetation, we hear grasshoppers nibbling in the verge and bees zipping in and out of their hive; we are met with rich mists, with 'vmbrate' branches dappling the grass, and can feel the warmth of the 'goldin bemis viuificatiue' replenishing the morning. Here are all the lavish 'tapestreis' of nature, splendidly set out.

But in a drastic qualification to this image (and to the long tradition of May prologues to which it belongs), Douglas allows his aureation to turn caustic. As he collapses into his dream, the green banks and beryl streams transmogrify into a river of blood and a blasted crag. The sound of the singing birds is monstrously changed into the sound of fish screaming. It is a passage that was admired by readers such as C.S. Lewis and W.H. Auden, in spite of the rather grim monotony of its rhyme words: ${ }^{19}$

My rauist spreit in that desert terribill Approchit neir that vglie flude horribill, Like till Cochyte the riuer Infernall, With vile water quihilk maid a hiddious trubil, Rinnand ouirheid, blude reid, and Impossibill That it had bene a riuer naturall;

With brayis bair, raif rochis like to fall, Quhairon na gers nor herbis wer visibill Bot [skauppis] brint with blastis boriall.

This laithlie flude rumland as thonder routit, In quhome the fisch zelland as eluis schoutit. Thair zelpis wilde my heiring all fordeifit.

Thay grym monstures my spreits abhorrit and doutit.

Not throw the soyl bot muskane treis sproutit, Combust, barrant, vnblomit and vnleifit, Auld, rottin runtis quhairen na sap was leifit, Moch, all waist, widderit, with granis moutit A ganand den quhair murtherars men reifit. 
Quhairfoir my seluin was richt sair agast.

This wildernes abhominabill and waist,

In quhome nathing was nature comfortand,

Was dark as [royk] the quhilk the sey vpcast.

The quhissilling wind blew mony bitter blast,

Runtis rattillit and vneith micht I stand.

Out throw the wod I crap on fute and hand.

The riuer stank, the treis clatterit fast,

The soyl was nocht bot marres, slike and sand.

(11. 136-62)

Douglas shows a singular willingness to dwell upon the clamours and textures of this environment. Many of his images do indeed have precedents in other literature (screaming fish were apparently taken to be a sign of the apocalypse) $;{ }^{20}$ but such images combine here to form a freshly horrendous scene. Even though there are only two rhyme endings in each stanza (AABAABBAB), Douglas weirdly opts for ' $\mathrm{A}$ ' and ' $\mathrm{B}$ ' rhymes that are barely distinguishable from one another ('horribill' and 'boriall'; 'routit' and 'reifit'). The insistent thickening of these sounds, which makes the scene so different from its analogues, compels the tongue to click incessantly on the palate, especially in words like 'routit', 'sproutit', 'rattillit', 'doutit', 'reifit', and 'clatterit'. It is a style of writing that engages the mouth as much as the ear, and although Douglas avoids excessive alliteration, his consonants are always pulsing along: 'Rinnand ouirheid, blude reid' (1. 140); 'Combust, barrant, vnblomit and vnleifit' (1. 150); 'dark as royk the quhilk the sey vpcast' (1. 157). And sounding aside, it is clear that he has chosen many of his words very precisely. In his description of the rotten tree trunks, for instance, nearly every clause contains a word or usage that appears for the first time in the written language:

Not throw the soyl bot muskane treis sproutit, Combust, barrant, vnblomit and vnleifit, Auld, rottin runtis quhairen na sap was leifit, Moch, all waist, widderit, with granis moutit 
These sprouting, putrefied runts are like nothing else in the dream vision tradition. Douglas's collocations have such particularity, and exert such terrible weight within the passage, that it is difficult to disagree with what C.S. Lewis sensed long ago: that such features of the dream 'really exist in their own right' and seem to defy allegorical interpretation. ${ }^{22}$

Reaching for this style of description within a dream vision was by no means a straightforward inheritance from fourteenth and fifteenth century poets. Although the gardens, rivers, and forests of works like The Assembly of Ladies or Lydgate's Complaint of the Black Knight did indeed occasion a diversity of incidents and intensities, it often sufficed for such poets simply to mention the presence of trees, or to describe the birds singing from the branches or the glittering of streams, before they felt their duty done, and could continue with the action of their poem. Even in Chaucer's House of Fame (the most significant analogue for The Palice of Honour as a whole), the desert that so unnerves 'Geffrey' appears insubstantial when read alongside that of Douglas:

Then sawgh I but a large feld, As fer as that I myghte see, Withouten toun, or hous, or tree, Or bush, or grass, or eryd lond; For al the feld nas but of sond As smal as man may se yet lye In the desert of Lybye.

(11. 482-88).

The very sprightliness of these couplets is strikingly at odds with the insistent clatter and mulch of the Scottish nightmare. It seems likely that the young Douglas was more captivated by the sublime, irreconcilable elements within Chaucer's descriptions, such as the tree trunks that are depicted on the walls of the Temple of Mars in 'The Knight's Tale': 'With knotty, knarry, bareyne trees olde, / Of stubbes sharpe and hidouse to biholde' (I. 1977-78); ${ }^{23}$ or the famous 'grisly rokkes blak' on the coast of Brittany, the very sight of which so appals Dorigen in 'The Franklin's Tale' (V. 859). But Douglas does not simply provide more detail than previous 
dreamers, he also integrates this detail into an immersive physical experience. When Lydgate writes, for instance, 'The soyle was pleyn, smothe, and wonder softe', ${ }^{24}$ he adds another touch to a descriptive tableau, but when Douglas says 'The soyl was nocht bot marres, slike and sand' he does so because he is crawling 'on fute and hand', fingering the soil's texture for himself (11. 160-62).

The various ideas about wilderness that would have been known to Douglas are familiar ones. Commenting on Aeneid VI. 131-32 (itself an important analogue for the wilderness of the Palice), Servius writes: 'dark woods and dens signify a place in which savagery and passion rule';25 while in the 1501 edition of Virgil that Douglas used, Badius Ascensius understands the forests of Avernus as a 'diversity of influences' in which wisdom (as figured by the golden bough) is difficult to find. ${ }^{26}$ A more pervasive homiletic trope held that life itself was 'bote an exil and a dezert' and that the whole world could 'lykend be / Til a forest in a wilde cuntre / Pat es ful of thefs and outlawes'. ${ }^{27}$ (In later life, Douglas would have to contend with the very real incursions of the 'Forest people' that dwelt in his Dunkeld bishopric.) ${ }^{28}$ These sorts of interpretive assumptions are made explicit in some fifteenth century visions, such as The Court of Sapience, in which an oracular authority immediately explains the meaning of a patch of wilderness: 'The desert place of fere thurgh which thou come / Is dredeful worldly occupacyon' $(11.162-63) .^{29}$

That Douglas's dreamwork is not so easily dissolved into a moral interpretation is what distinguishes it from many of its antecedents: there are real trees in his allegorical forest. Not only does he describe the appearance of these trees in such vivid terms, he actually crawls inside a hollow one for safety, where he is profoundly disturbed by the thought that a mouse might squeak at him: 'The stichling of a mous out of presence / Had bene to me mair vgsom than the Hell' (11. 308-09). When he is eventually discovered inside his 'muskane aikin stok misharrit' by Venus's thuggish followers, they mock him as a 'reclus imperfite' (1. 645), 
apparently recalling the fact that hermits were sometimes known to live inside of tree trunks. ${ }^{30}$ Finally, when he has been released from Venus's court by Calliope and her 'Court Rethoricall', he sits down 'on ane stock' to compose a poem for his former captor (1. 1013). It is remarkable to see a medieval dreamer interact so particularly and so consistently with the topography of his dream, especially when compared with contemporary works by Stephen Hawes, William Neville, and John Skelton, in which long passages of direct speech tend to predominate at the expense of a coherent setting.

The wilderness of the Palice reveals just how willing Douglas was to expand a description of landscape far beyond the usual expectations of a genre. It is a reminder not only of how flexible and assimilative the dream vision tradition really was, but also how its conventions could become a site of resistance and transformation for a virtuosic young poet. Douglas experiments with extreme contrasts and sudden shifts in tone, but he is also sensitive to the comic possibilities of plunging a terrified observer into a highly substantiated environment. The seasonal pattern of 'Ver translait in winter furious' (1. 190) is a source of dramatic energy, but it is also a telling anticipation of the contrast between Prologues VII and XII of the Eneados.

But how does the 'winter furious' of the Palice relate to the famous winter scene of Prologue VII? Although the squelching soil, the bare rock, and the dark mists all return in the later work, it is clear that Douglas did not wish to achieve the same effects in these two landscapes. The naturalism of Prologue VII, which 'smellis new cum furth of hell' (VII. Prol. 163), appears just after Aeneas has emerged from the underworld at the end of Aeneid VI, and as a 'drery preambill' to Aeneid VII, it also anticipates the hellishness of open warfare. By contrast, the eldritch imaginings of the Palice (though they contain many comic gestures towards Aeneid VI), ${ }^{31}$ seem more closely to resemble the nightmares of Lichtoun, Rowll, and Dunbar, in which hell is a rollicking world of dragon-headed demons and gluts of excrement, 
and in which the very notion of solemnity and ethical profundity is dissolved into laughter and ritual humiliation.

By 1513, however, Douglas was mocking those who could not distinguish between the sort of 'bogillis' and 'elrich fantasyis' of the vernacular (VI. Prol. 17-18) and the grandeur and stateliness of the classical underworld. The philosophical seriousness of Aeneid VI had come to be a key principle in Douglas's poetics, and twelve years after his adventure in hellish burlesque, he was no longer content to be exuberant in his dealings with the underworld. Prologue VII was the most sustained description of winter that had ever been attempted by a poet whose work survives, but within its frozen landscape, it also managed to evince a solemn vision of hell:

The soyl ysowpit into water wak,

The firmament ourcast with rokis blak,

The grond fadyt, and fawch wolx all the feildis, Montane toppis slekit with snaw ourheildis;

On raggit rolkis of hard harsk quhyn stane

With frosyn frontis cauld clynty clewis schane.

Bewte was lost, and barrand schew the landis,

With frostis hair ourfret the feldis standis.

Seir bittir bubbis and the schowris snell

Semyt on the sward a symylitude of hell,

Reducyng to our mynd, in every sted,

Gousty schaddois of eild and grisly ded.

(VII. Prol. 35-46)

His descriptive technique has clearly changed since 1501 . There is a more frequent use of alliteration (to a fault, perhaps, in 'cauld clynty clewis schane') but the absence of so demanding a rhyme scheme makes the texture of the lines more varied, and allows for a subtler manipulation of perspective. Douglas looks to the waterlogged soil, but then raises his eyes to observe that 'fawch wolx all the feildis'; he surveys the 'Montane toppis' (tellingly the first recorded instance of the phrase), and evokes with slow, immovable monosyllables a sense of the 'hard harsk quhyn stane', before memorably declaring, 'Bewte was lost, and barrand schew 
the landis'. It is a passage which (to re-apply Samuel Johnson's praise of James Thomson) 'at once comprehends the vast, and attends to the minute'. ${ }^{32}$ Indeed, the very idea that a rugged mountain range and a blown fen could suggest to the mind 'Gousty schaddois of eild and grisly ded' reminds us not so much of Henryson as it does of the Burkean sublime, or even the hailbeaten hell of Paradise Lost, with its 'Rocks, caves, lakes, fens, bogs, dens, and shades of death, / A universe of death' ${ }^{33}$

The landscape of Prologue VII differs with that of the Palice not only in tone, but for the way in which the observer's perspective is educed in relation to his environment. The image of a man cowering haplessly in a tree trunk, convinced that he will be 'deuoirit with sum beist rauenous' (Palice, 1. 170), has an element of farce that is entirely absent from the gently comic scene in Prologue VII in which the poet gets ready for bed, crosses himself, and wraps up in 'clathis thrynfald' to protect against 'the peralus persand cald' (11. 95-96). As he falls asleep, it is only the screech of the night owl that reminds us of the terrible noises of the Palice:

Hornyt Hebowd, quhilk we clepe the nycht owle, Within hir cavern hard I schowt and zowle, Laithly of form, with crukyt camscho beke, Vgsum to heir was hir wild elrich screke

The relationship between the May prologue of the Palice and Prologue XII of the Eneados is somewhat less enigmatic, but it vividly suggests how the qualities of perspective, spatial consistency and attention to detail developed in Douglas's landscape poetry. In Prologue XII - which he titled 'perle of May' (XII. Prol. 307) - Douglas carefully revises certain lines and images that he had used in the opening passage of the Palice. Had these works been written by two different poets, some of the echoes could be attributed to a shared tradition, but Douglas presumably remembered what he had written as a young man, and was aware of what effects he could achieve by altering the context and diction of his own earlier material. 
In the formal hymn to May that occurs in the prologue of the Palice, for instance, there appears this description of birds:

Thy mirth refreschis byrdis in thair nestis, Quhilks the to prise and nature neuer restis, Confessand zow maist potent and louabill Amang the brownis of the oliue twystis.

At some point in the intervening years, Douglas revisited one of these lines, but developed it in a new direction. Though his birds remain substantially the same, he now apprehends them in relation to spiders, midges, and flies:

Amang the bronys of the olyve twestis

Seir smaill fowlys wirkand crafty nestis, Endlang the heggeis thyk and on rank akis, Ilk byrd reiosyng with thar myrthfull makis.

In corneris and cleir fenystaris of glas

Full bissely Aragne wevand was,

To knyt hir nettis and hir wobbys sle, Tharwyth to caucht the myghe and litill fle.

(XII. Prol. 165-72)

In many ways, it is a momentous shift in perspective. There is no reason why the appearance of a spider should be so surprising in this context, and yet, having read through the landscape poetry of Douglas's predecessors, one could be forgiven for forgetting that spiders ever existed. (Chaucer only ever thinks of a 'lopweb' when he is describing the appearance of an astrolabe's rete. $)^{34}$ But here, off in the corner, there are more creatures living and moving on their own terms than one might otherwise have thought. By training his eyes on the less familiar recesses of his environment (what he memorably terms 'the scroggis'), Douglas could achieve a new suggestion of depth in his scenery. Even so innocuous a phrase as 'Endlang the heggeis thyk' (1. 167) allows the foliage to extend off into the distance. 
A more dramatic instance of this effect can be seen in the revised version of another image from the Palice, that of the sunbeams 'portraying' the shapes of the branches onto the ground:

The vmbrate treis that Tytan about wappit

War portrait and on the eirth yschappit

Be goldin bemis viuificatiue

When Douglas revisits this idea in Prologue XII he also remembers an entirely unrelated moment from his earlier poem, in which he enumerates the gothic spires and buttresses of the 'Palice of Honour' itself:

Pinnakillis, Fyellis, Turnpekkis mony one, Gilt birneist torris, quhilk like to Phebus schone, Skarsment, Reprise, Corbell and Battellingis, Fulzery, bordouris of mony precious stone,

Subtile muldrie wrocht mony day agone

On Buttereis, Ialme, pillaris and plesand springis...

This is Douglas at his least attractive. As is often the case in the Palice, he depends upon the steady accumulation of detail - the pinnacles, the turnpikes, the turrets - to achieve his desired effect, but as one early critic remarked, the resulting passage reads rather like 'a specification for a monastic architect'. ${ }^{35}$ In Prologue XII, however, these feats of architecture are wholly reconfigured by the play of the morning light. As the sun rises, it paints not only a shadowed image of the branches onto the ground, but unites those natural aspects of the landscape with those that are manmade:

The swardit soyll enbrovd with selcouth hewys, Wod and forest obumbrat with thar bewys, Quhois blisfull branschis, porturat on the grund, With schaddoys schene schew rochis rubicund;

Towris, turettis, kyrnellis, pynnaclys hie Of kyrkis, castellis and ilke fair cite, Stude payntit, euery fyall, fayn and stage, 
Apon the plane grund, by thar awyn vmbrage.

(XII. Prol. 65-72)

The massed intricacies of human architecture rear up, just above the woods and forests, but are likewise dissolved and shadowed 'Apon the plane grund'. The syntax is itself massed and intricate, but invariably converges - in spite of its minor runs of catalogue - upon the same 'plane grund'. If there is a unifying principle in the twelfth prologue, it is this assimilative perception of light, how it suggests the interrelatedness of what had formerly been seen only in studied isolation.

This process of revision and expansion sheds important light on the compositional techniques behind Douglas's twelfth prologue, and clarifies some of the stylistic continuities and discontinuities between his two major works. The full implications of such revisions are not a matter of diction alone. The structure of the Palice had allowed a version of 'Purgatorie' (1. 623) to be arrested within the mind of a dreaming individual, but in Prologue XII the workings of despair, however totalising, must also take their place in the sunlit landscape:

And thochtfull luffaris rowmys to and fro,

To lys thar pane, and pleyn thar ioly wo,

Eftir thar gys, now syngand, now in sorow,

With hartis pensyve, the lang symmyris morow:

Sum ballettis lyst endyte of hys lady,

Sum levis in hoip, and sum aluterly

Disparit is, and sa quyte owt of grace,

Hys purgatory he fyndis in euery place.

(XII. Prol. 201-08)

These verses have the sort of rich and varied movement that is often wanting in the nine line stanza of the Palice. In the couplets we find a greater subtlety of sounds, such as the mellow half rhyme of 'wo' and 'sorow', or the expressive lengthening of 'sorow' into 'lang symmyris morow'. The disposition of clauses also has a greater variety, as when the word 'aluterly' is given a brief moment to gather itself before a dejected slump: 
Sum levis in hoip, and sum aluterly

Disparit is

This careful unbalancing of the verse is all the more affecting if the reader has in mind the passage that Douglas is reworking from his earlier poem. At the end of an exhaustive description of the court of Venus in The Palice of Honour (11. 400-606), a similar set of lovers comes trooping into focus:

Sum leuis in hope and sum in greit thirlage,

Sum in dispair, sum findis his panis swage.

(Palice, 11. 601-02)

These figures seem, by contrast, all too evenly aligned within the cadence of each line. Returning to Prologue XII, we may appreciate afresh how the slight metrical tilt that Douglas introduces can then steady itself so gravely along the concluding line:

Sum levis in hoip, and sum aluterly Disparit is, and sa quyte owt of grace, Hys purgatory he fyndis in euery place.

The question of whether Douglas 'invented' nature poetry becomes rather remote when we are faced with the delicacy of such revisions. For although the 'thochtfull luffaris' of Prologue XII are seemingly reduced to mere ciphers in the distance, becoming ordinary fixtures within the mechanism of nature, in the end it is their very faintness that Douglas succeeds in capturing. As his prologue expands to include furtive conversations, or spiders, or snatchings of song, its full view reminds us that human experiences are at once accentuated and diminished when they are seen in relation to landscape. Douglas could achieve this fine balance only after a long apprenticeship. 
NOTES

${ }^{1}$ References to Douglas's Eneados are to Gavin Douglas, Virgil's Aeneid Translated into Scottish Verse, ed. David F.C. Coldwell, 4 vols. (Edinburgh, 1957-64). References to The Palice of Honour are to the Edinburgh text of 1579 as printed in The Shorter Poems of Gavin Douglas, ed. Priscilla Bawcutt (Edinburgh, 1967 rev. 2003); chain brackets indicate an emendation from the London text of c.1553 (also printed by Bawcutt). I have silently expanded abbreviations and have standardised capitalisation. Line references for the descriptions of wind: Eneados I. ii. 6; III. ii. 3; The Palice of Honour 1. 1365; Eneados X. vi. 155; VII. Prol. 123; Palice 1. 1364; Eneados V. iv. 99; IV. viii. 73; I. iii. 16; X. xi. 175; I. ii. 52; XII. vi. 136; V. i. 34; VI. Xii. 42; XII. Prol. 75; VII. Prol. 88;

2 I. Prol. 117; I. Prol. 103.

${ }^{3}$ John Ruskin, The Works of John Ruskin, ed. E.T. Cook and Alexander Wedderburn, 39 vols. (1903-12), xxxvii. p. 333. For the grouping with Dante see vol. xxxiii, pp. 119, 137, and vol. xxxiv, p. 338.

${ }^{4}$ Ezra Pound, Literary Essays (1954), p. 35.

${ }^{5}$ T.S. Eliot, The Complete Prose of T.S. Eliot: The Critical Edition, gen. ed. Ronald Schuchard, 8 vols. (projected) (2014-), ii. pp. 93, 96, n. 4.

${ }^{6}$ On Sackville, see Priscilla Bawcutt, Gavin Douglas: A Critical Study (Edinburgh, 1976), pp. 199-200. Thomas Gray, The Works of Thomas Gray, 5 vols (1843), vol. v, p. 36. Auden included 11. 1-72 of Prologue XII in A Certain World (1971), pp. 96-98. On Auden's use of Douglas, see Conor Leahy, 'Forests of Green: W.H. Auden and Older Scots Poetry', TLS, 5857 (3 July 2015), 14-15. 
${ }^{7}$ Alastair Fowler, 'Gavin Douglas: Romantic Humanist', in Alasdair A. MacDonald and Kees Dekker (eds.), Rhetoric, Royalty, and Reality: Essays on the Literary Culture of Medieval and Early Modern Scotland (Paris, 2005), pp. 83-103: 103.

${ }^{8}$ W.W. Skeat (ed.), Complete Works of Geoffrey Chaucer, 7 vols. (Oxford, 1894-97): i. 44, n. 2 (a comment on The Floure and the Leafe). H.S. Bennett, Chaucer and the Fifteenth Century (Oxford, 1947), p. 126.

${ }^{9}$ Many of these debts were first examined in Bawcutt, Gavin Douglas, pp. 175-90.

${ }^{10}$ Robert Henryson, The Poems of Robert Henryson, ed. Denton Fox (Oxford, 1981), p. 67.

11 All references to Chaucer are to The Riverside Chaucer (third edition), gen. ed. Larry D. Benson (Oxford, 2008).

${ }^{12}$ The similarity between the second line of The Palice of Honour and Horatio's 'morn in russet mantle clad' was noted as early as 1879 . See Sidney Lanier, Shakspeare and his Forerunners (1902), p. 62.

${ }^{13}$ Henryson, Fables, p. 66 (1. 1677).

${ }^{14}$ Servius, Servii grammatici qui feruntur in Vergilii carmina commentarii, ed. Georg Thilo and Hermann Hagen, 2 vols (Hildesheim, 1961), ii. 30-31.

${ }^{16}$ Fowler, 'Gavin Douglas: Romantic Humanist', p. 105.

17 Bawcutt, The Shorter Poems of Gavin Douglas, p. xxix. Bawcutt's edition provides a comprehensive introduction, notes, and a review of scholarship

${ }^{18}$ Douglas's dreaming self is addressed as 'galland' (1. 1308) and is classed among 'kirkmen' (1. 1944).

${ }^{19}$ C.S. Lewis, The Allegory of Love (Oxford, 1936), pp. 290-92. Auden selected 11. 136-192 of the Palice for Poets of the English Language, Vol. 1: Langland to Spenser, ed. W.H. Auden and Norman Holmes Pearson (1952), pp. 323-25. 
${ }^{20}$ Alicia K. Nitecki, 'Gavin Douglas's Yelling Fish: The Palice of Honour, Lines 146-8', Notes and Queries, 28 (2) (1981), pp. 118-9.

${ }^{21}$ See $A$ Dictionary of the Older Scottish Tongue (DOST), ed. William A. Craigie, A. J. Aitken, et al. (Chicago, 1931-2002), s.v. 'Muskane, muscane' adj.; s.v. 'Unblomit, -blomyt' ppl. adj.; s.v. 'Unleifit, -levyt' p.p.; s.v. 'Runt' n. (cp. $O E D$ s.v. 'runt' n. 2a); s.v. 'Moch, moich' adj.; s.v. 'Grain(e, grane' n. ${ }^{2} 1$ (cp. OED 'grain', n. $\left.{ }^{2} 2\right)$; s.v. 'Moutit, mutit, muttit' ppl. adj.

${ }^{22}$ Lewis, Allegory of Love, p. 291.

${ }^{23}$ This analogue is noted by David Parkinson in his edition of the poem, The Palis of Honoure (Kalamazoo, Mich., 1992).

${ }^{24}$ John Lydgate, The Complaint of the Black Knight (1. 50) in The Minor Poems of John Lydgate, Part II: Secular Poems (1934), p. 384.

25 '[P]er silvas tenebras et lustra significat, in quibus feritas et libido dominantur'. Servius, commentarii, ii. 28.

26 'Per sylvam igitur significatur nobis diuersitas influentiarum: in qua difficile est illum aureum ramum de quo in sexto mentio fiet inuenire'. Aeneis Vergiliana, ed. Jodocus Badius Ascensius (Paris, 1501), fol. 231 ${ }^{\mathrm{r}}$.

${ }^{27}$ Dan Michel's Ayenbite of Inwyt, ed. Richard Morris (1866), p. 131. Richard Morris's Prick of Conscience: A Corrected and Amplified Reading Text, ed. Ralph Hanna and Sarah Wood (Oxford, 2013), p.37 (11. 1235-37).

${ }^{28}$ The Poetical Works of Gavin Douglas, ed. John Small, 4 vols. (Edinburgh, 1874), i. 1xxix.

${ }^{29}$ The Court of Sapience, ed. E. Ruth Harvey (Toronto, 1984), p. 8.

${ }^{30}$ Jacques Lacarrière, The God-Possessed, trans. Roy Monkcom (1963), pp. 27-28, 152.

${ }^{31}$ See David Parkinson, 'The Farce of Modesty in Gavin Douglas's The Palis of Honoure', Philological Quarterly, 70 (1990), pp. 13-25: 16.

${ }^{32}$ Samuel Johnson, The Lives of the Poets, 4 vols, ed. Roger Lonsdale (Oxford, 2006), iv. 103. 
33 John Milton, Paradise Lost, ed. Alastair Fowler (1968 rev. 1997), p. 140 (II. 621-22).

${ }^{34}$ Chaucer, A Treatise on the Astrolabe, I. xxi. 2; also I. iii. 5 and I. xix. 2-3.

${ }^{35}$ G. Gregory Smith, The Transition Period (1900), p. 60. 